\title{
Seven years of external control of fluoride levels in the public water supply in Bauru, São Paulo, Brazil
}

\author{
Marília Afonso Rabelo BUZALAF¹, Camila Mascarenhas MORAES ${ }^{2}$, Kelly Polido Kaneshiro OLYMPIO ${ }^{3}$, Juliano \\ Pelim PESSAN ${ }^{4}$, Larissa Tercília GRIZZO ${ }^{5}$, Thelma Lopes SILVA ${ }^{5}$, Ana Carolina MAGALHÃES ${ }^{6}$, Rodrigo Cardoso de \\ OLIVEIRA $^{6}$, Sonia GROISMAN ${ }^{7}$, Irene RAMIRES ${ }^{8}$
}

\author{
1- DDS, MSc, PhD, Full Professor, Discipline of Biochemistry, Department of Biological Sciences, Bauru School of Dentistry, University of São Paulo, Bauru, \\ SP, Brazil. \\ 2- DDS, Bauru School of Dentistry, University of São Paulo, Bauru, SP, Brazil. \\ 3- DDS, MSc, PhD, Department of Biological Sciences, Bauru School of Dentistry, University of São Paulo, Bauru, SP, Brazil. \\ 4- DDS, MSc, PhD, Professor, Department of Pediatric Dentistry, Araçatuba Dental School, Univ. Estadual Paulista - UNESP, Araçatuba, SP, Brazil. \\ 5- BSc, Bauru School of Dentistry, University of São Paulo, Bauru, SP, Brazil. \\ 6- DDS, MSc, PhD, Professor, Department of Biological Sciences, Bauru School of Dentistry, University of São Paulo, Bauru, SP, Brazil. \\ 7- DDS, MSc, PhD, Professor, Department of Social and Preventive Dentistry, Federal University of Rio de Janeiro, Rio de Janeiro, Brazil. \\ 8- DDS, MSc, Department of Biological Sciences, Bauru School of Dentistry, University of São Paulo, Bauru, SP, Brazil.
}

Corresponding address: Profa. Dra. Marília Afonso Rabelo Buzalaf - Faculdade de Odontologia de Bauru - USP - Departamento de Ciência Biológicas Disciplina de Bioquímica - Al. Dr. Octávio Pinheiro Brisolla, 9-75 - Vila Universitária - 17012-101 - Bauru - SP - Brazil - e-mail: mbuzalaf@fob.usp.br

Received: March 6, 2012 - Modification: September 27, 2012 - Accepted: October 23, 2012

\section{ABSTRACT}

\begin{abstract}
Fluoridation of the public water supplies is recognized as among the top ten public health achievements of the twentieth century. However, the positive aspects of this measure depend on the maintenance of fluoride concentrations within adequate levels. Objective: To report the results of seven years of external control of the fluoride (F) concentrations in the public water supply in Bauru, SP, Brazil in an attempt to verify, on the basis of risk/ benefit balance, whether the levels are appropriate. Material and Methods: From March 2004 to February 2011, 60 samples were collected every month from the 19 supply sectors of the city, totaling 4,641 samples. F concentrations in water samples were determined in duplicate, using an ion-specific electrode (Orion 9609) coupled to a potentiometer after buffering with TISAB II. After the analysis, the samples were classified according to the best risk-benefit adjustment. Results: Means ( \pm standard deviation) of $\mathrm{F}$ concentrations ranged between $0.73 \pm 0.06$ and $0.81 \pm 0.10 \mathrm{mg} / \mathrm{L}$ for the different sectors during the seven years. The individual values ranged between 0.03 and $2.63 \mathrm{mg} / \mathrm{L}$. The percentages of the samples considered "low risk" for dental fluorosis development and of "maximum benefit" for dental caries prevention (0.55-0.84 mg F/L) in the first, second, third, fourth, fifth, sixth, and seventh years of the study were $82.0,58.5,37.4,61.0,89.9,77.3$, and $72.4 \%$, respectively, and $69.0 \%$ for the entire period. Conclusions: Fluctuations of $\mathrm{F}$ levels were found in the public water supply in Bauru during the seven years of evaluation. These results suggest that external monitoring of water fluoridation by an independent assessor should be implemented in cities where there is adjusted fluoridation. This measure should be continued in order to verify that fluoride levels are suitable and, if not, to provide support for the appropriate adjustments.
\end{abstract}

Key words: Fluoridation. Water treatment. Water analysis. Fluorides. Oral health.

\section{INTRODUCTION}

Water fluoridation has been identified by the Centers for Disease Control and Prevention as one of the top ten greatest public health achievements of the $20^{\text {th }}$ century because it is an inexpensive scientifically justified and broad-range method to prevent dental caries in the population ${ }^{7}$. Systematic reviews have recognized fluoridation of drinking water supplies as the most effective and socially equitable measure to promote the preventive effects of fluoride ${ }^{20,34}$. However, the positive aspects 
of the fluoridation of water supply are related to the maintenance of adequate fluoride levels. It has been acknowledged that low levels of fluoride in the oral fluids are effective in controlling dental caries in those who drink the water ${ }^{10,32}$.

Regarding water fluoride concentrations, the "therapeutic ratio" is low ${ }^{27}$. The space between the two dis-benefits - insufficiency with increased risk of dental caries ${ }^{8}$ - and excess with increased risk of fluorosis ${ }^{8,19}$ - is small. Thus, in order to maximize the benefits of water fluoridation, a balance between too little and too much fluoride must be maintained ${ }^{27}$. The need to develop control mechanisms for fluoridation has led to the emergence of the concept of external control. It is the principle by which, if an item or service involves risk or benefit for public health, then, besides the producer's control over the production, distribution, and consumption process, there must also be control by a third party. The implementation of surveillance systems based on external control can be an effective contribution toward improving the quality of water fluoridation ${ }^{23}$.

Several dental and health organizations, such as the International Association for Dental Research (IADR), the European Organization for Caries Research (ORCA), the Pan-American Health Organization (PAHO), the World Health Organization (WHO), and the World Dental Federation (FDI $)^{28}$, support the fluoridation of water supplies. In Brazil, Federal Law $6050^{3}$ (1974), regulated by the Act $76872^{4}$ (1975), states that public water supplies should be fluoridated whenever water treatment is performed. For Brazilian municipalities in warm weather climates, the optimal fluoride concentration in the water is about $0.7 \mathrm{mg} / \mathrm{L}$, with an acceptable range of 0.6 to $0.8 \mathrm{mg} / \mathrm{L}^{21}$. In order to stay within this acceptable range, operational control is essential and should be implemented by the sanitation company to guarantee the high quality of the water provided to consumers, as required by legislation ${ }^{24}$.

However, studies have revealed fluctuations in the fluoride concentrations in public water supplies in different regions of Brazil2,5,16,18,25,30,33. In Bauru, state of São Paulo, fluoridation of the public water supply was implemented in 1975. Since then, reports have shown inconsistencies in the fluoridation levels ${ }^{5,17,31}$. In an attempt to improve this situation, external control over the fluoridation of the public water supply was implemented in the municipality in 2004 by Bauru School of Dentistry (University of São Paulo). The aim of this study is to describe what was found during the first seven years (2004-2011) that this external control was implemented to determine whether public water fluoride concentrations were maintained at the appropriate levels, based on the risk/benefit balance.

\section{MATERIAL AND METHODS}

Bauru is a warm-weather city, with an annual mean maximum temperature of $27.9^{\circ} \mathrm{C}^{13}$. It is located in the midwestern region of the state of São Paulo (the southeastern region of Brazil), with a population of around $344,000^{12}$. Water that is supplied to the population undergoes conventional treatments of chlorination and fluoridation. The supply system is not the same for the entire city. A network of pipes from the water treatment station supplies water to $44 \%$ of the population (from surface water) and the remaining $56 \%$ of the population is supplied by 27 artesian wells. The system is divided into 19 sectors, as described by Ramires, et al. ${ }^{26}$ (2006). Each sector is individually fluoridated, which makes attempts at quality control quite difficult.

The scheme for collecting water samples was based on the characteristics of the various supply sectors (Figure 1). Three sample collection points were established for each of the 19 sectors, except for the sector supplied by the water treatment station, which had six sample collection points due to its large size and because it is surrounded by many other sectors.

According to this protocol, 60 water samples

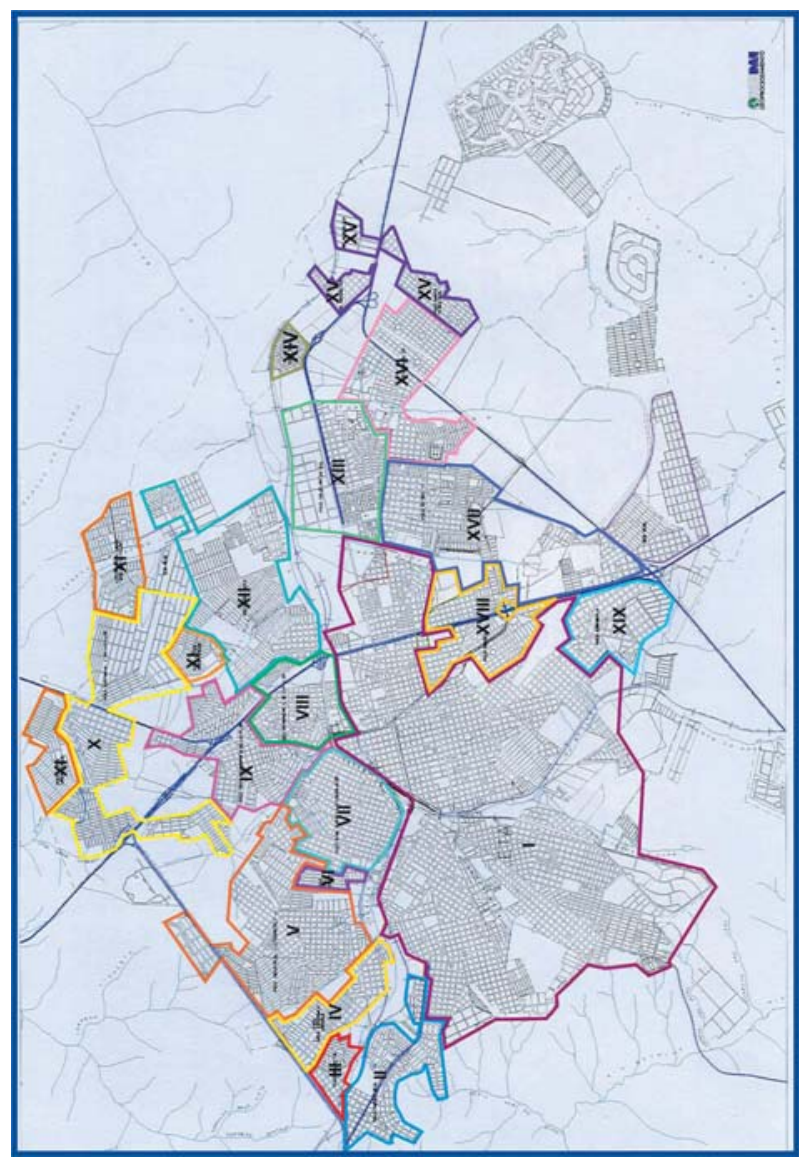

Figure 1- Localization of the 19 sectors of water supply, Bauru $^{26}, 2006$ 
should be collected each month, totaling 720 samples per year. Therefore, the number of samples analyzed for the period March 2004 to February 2011 was 5,040. The collection points were located at public institutions, primary health care units, and state and municipal schools, in order to make site access easy and to avoid losses. Before beginning, the researchers sent official explanatory letters to the Bureaus of Education and Health and the Sectional Directory of Education, which authorized the study.

Plastic vials were used for sample collection. Each vial was labeled in advance to identify its sector, collection point, and date of collection. At the end of the collection day, the samples $(50 \mathrm{~mL})$ were stored at $-20^{\circ} \mathrm{C}$ for up to one week for subsequent fluoride analysis.

Fluoride concentrations in the water samples were determined via an ion-specific electrode (Orion 9609, Thermo Scientific, Beverly, MA, USA) coupled to a potentiometer (Procyon, model 720, Procyon Instrumentos Científicos Ltda, São Paulo, SP, Brazil). In this procedure, $1 \mathrm{~mL}$ of the sample was mixed with $1 \mathrm{~mL}$ of TISAB II to buffer the solution and provide adequate ionic strength. The electrode had previously been calibrated with standard

Table 1- Mean fluoride concentrations ( $\mathrm{mg} / \mathrm{L})$ in the water samples, according to public supply sectors, Bauru, Brazil, from March/2004 to February/2011

\begin{tabular}{|c|c|c|c|c|c|c|c|c|}
\hline \multirow[b]{2}{*}{ Sector } & \multicolumn{8}{|c|}{ Years of water sample collections } \\
\hline & $1^{\text {st }}$ year & $2^{\text {nd }}$ year & $3^{\text {rd }}$ year & $4^{\text {th }}$ year & $5^{\text {th }}$ year & $6^{\text {th }}$ year & $7^{\text {th }}$ year & Mean $\pm S D$ \\
\hline \multirow[t]{2}{*}{$\mathrm{I}$} & $0.69 \pm 0.10$ & $0.76 \pm 0.11$ & $0.82 \pm 0.12$ & $0.83 \pm 0.08$ & $0.74 \pm 0.06$ & $0.72 \pm 0.07$ & $0.58 \pm 0.06$ & $0.73 \pm 0.08$ \\
\hline & $(0.05-0.87)$ & $(0.03-1.07)$ & $(0.03-0.98)$ & $(0.68-1.03)$ & $(0.59-0.99)$ & $(0.53-0.89)$ & $(0.32-0.77)$ & \\
\hline \multirow[t]{2}{*}{ II } & $0.73 \pm 0.07$ & $0.83 \pm 0.10$ & $0.86 \pm 0.11$ & $0.80 \pm 0.11$ & $0.71 \pm 0.06$ & $0.68 \pm 0.06$ & $0.62 \pm 0.08$ & $0.75 \pm 0.09$ \\
\hline & $(0.35-0.87)$ & $(0.58-1.25)$ & $(0.62-1.08)$ & $(0.64-1.02)$ & $(0.53-0.87)$ & $(0.51-0.79)$ & $(0.50-0.79)$ & \\
\hline \multirow[t]{2}{*}{ III } & $0.80 \pm 0.12$ & $0.91 \pm 0.31$ & $0.92 \pm 0.13$ & $0.82 \pm 0.11$ & $0.72 \pm 0.09$ & $0.71 \pm 0.07$ & $0.64 \pm 0.09$ & $0.79 \pm 0.10$ \\
\hline & $(0.54-0.98)$ & $(0.56-1.78)$ & $(0.70-1.15)$ & $(0.68-1.22)$ & $(0.50-0.85)$ & $(0.56-0.82)$ & $(0.33-1.08)$ & \\
\hline \multirow[t]{2}{*}{ IV } & $0.73 \pm 0.12$ & $0.80 \pm 0.10$ & $0.86 \pm 0.08$ & $0.82 \pm 0.11$ & $0.74 \pm 0.08$ & $0.71 \pm 0.08$ & $0.61 \pm 0.11$ & $0.75 \pm 0.08$ \\
\hline & $(0.54-0.97)$ & $(0.56-1.02)$ & $(0.73-1.01)$ & $(0.70-1.24)$ & $(0.50-0.90)$ & $(0.57-0.82)$ & $(0.27-0.97)$ & \\
\hline \multirow[t]{2}{*}{ V } & $0.74 \pm 0.08$ & $0.82 \pm 0.12$ & $0.84 \pm 0.12$ & $0.76 \pm 0.07$ & $0.74 \pm 0.08$ & $0.72 \pm 0.11$ & $0.57 \pm 0.09$ & $0.74 \pm 0.09$ \\
\hline & $(0.59-0.90)$ & $(0.68-1.15)$ & $(0.63-1.01)$ & $(0.44-0.91)$ & $(0.58-0.92)$ & $(0.51-0.96)$ & $(0.21-0.73)$ & \\
\hline \multirow[t]{2}{*}{ VI } & $0.74 \pm 0.07$ & $0.81 \pm 0.12$ & $0.83 \pm 0.13$ & $0.71 \pm 0.09$ & $0.72 \pm 0.08$ & $0.74 \pm 0.10$ & $0.60 \pm 0.08$ & $0.74 \pm 0.08$ \\
\hline & $(0.59-0.92)$ & $(0.67-1.13)$ & $(0.53-1.01)$ & $(0.44-0.87)$ & $(0.60-0.89)$ & $(0.50-0.98)$ & $(0.43-0.69)$ & \\
\hline \multirow[t]{2}{*}{ VII } & $0.73 \pm 0.08$ & $0.83 \pm 0.13$ & $0.88 \pm 0.10$ & $0.85 \pm 0.07$ & $0.75 \pm 0.07$ & $0.76 \pm 0.10$ & $0.61 \pm 0.08$ & $0.77 \pm 0.09$ \\
\hline & $(0.59-0.92)$ & $(0.65-1.15)$ & $(0.57-1.13)$ & $(0.64-0.97)$ & $(0.56-0.92)$ & $(0.42-0.93)$ & $(0.47-0.75)$ & \\
\hline \multirow[t]{2}{*}{ VIII } & $0.75 \pm 0.07$ & $0.86 \pm 0.13$ & $0.91 \pm 0.12$ & $0.83 \pm 0.08$ & $0.77 \pm 0.06$ & $0.76 \pm 0.11$ & $0.64 \pm 0.08$ & $0.79 \pm 0.09$ \\
\hline & $(0.64-0.91)$ & $(0.65-1.30)$ & $(0.65-1.12)$ & $(0.62-1.13)$ & $(0.64-0.96)$ & $(0.56-0.96)$ & $(0.51-0.76)$ & \\
\hline \multirow[t]{2}{*}{ IX } & $0.76 \pm 0.07$ & $0.84 \pm 0.12$ & $0.88 \pm 0.10$ & $0.81 \pm 0.09$ & $0.76 \pm 0.07$ & $0.78 \pm 0.10$ & $0.64 \pm 0.08$ & $0.78 \pm 0.08$ \\
\hline & $(0.61-0.91)$ & $(0.62-1.07)$ & $(0.56-1.08)$ & $(0.49-1.05)$ & $(0.60-0.94)$ & $(0.53-0.96)$ & $(0.50-0.82)$ & \\
\hline \multirow[t]{2}{*}{$x$} & $0.74 \pm 0.07$ & $0.80 \pm 0.13$ & $0.91 \pm 0.12$ & $0.92 \pm 0.19$ & $0.76 \pm 0.05$ & $0.79 \pm 0.10$ & $0.61 \pm 0.07$ & $0.79 \pm 0.11$ \\
\hline & $(0.63-0.91)$ & $(0.56-1.11)$ & $(0.66-1.13)$ & $(0.70-2.63)$ & $(0.67-0.88)$ & $(0.56-0.93)$ & $(0.49-0.82)$ & \\
\hline \multirow[t]{2}{*}{ XI } & $0.80 \pm 0.10$ & $0.84 \pm 0.21$ & $0.92 \pm 0.13$ & $0.91 \pm 0.14$ & $0.75 \pm 0.05$ & $0.79 \pm 0.09$ & $0.64 \pm 0.08$ & $0.81 \pm 0.10$ \\
\hline & $(0.63-1.44)$ & $(0.55-1.23)$ & $(0.67-1.20)$ & $(0.72-1.54)$ & $(0.63-0.85)$ & $(0.59-0.93)$ & $(0.52-0.85)$ & \\
\hline \multirow[t]{2}{*}{ XII } & $0.77 \pm 0.07$ & $0.85 \pm 0.12$ & $0.91 \pm 0.12$ & $0.81 \pm 0.10$ & $0.74 \pm 0.06$ & $0.78 \pm 0.12$ & $0.60 \pm 0.09$ & $0.78 \pm 0.10$ \\
\hline & $(0.65-0.96)$ & $(0.65-1.12)$ & $(0.71-1.10)$ & $(0.68-1.06)$ & $(0.64-0.89)$ & $(0.49-1.01)$ & $(0.07-0.73)$ & \\
\hline \multirow[t]{2}{*}{ XIII } & $0.70 \pm 0.08$ & $0.90 \pm 0.18$ & $0.87 \pm 0.11$ & $0.78 \pm 0.17$ & $0.75 \pm 0.08$ & $0.77 \pm 0.10$ & $0.55 \pm 0.11$ & $0.76 \pm 0.12$ \\
\hline & $(0.11-0.85)$ & $(0.73-1.29)$ & $(0.67-1.06)$ & $(0.19-1.04)$ & $(0.45-1.11)$ & $(0.55-0.98)$ & $(0.21-0.75)$ & \\
\hline \multirow[t]{2}{*}{ XIV } & $0.69 \pm 0.14$ & $0.87 \pm 0.14$ & $0.91 \pm 0.20$ & $0.80 \pm 0.19$ & $0.77 \pm 0.06$ & $0.72 \pm 0.15$ & $0.63 \pm 0.08$ & $0.77 \pm 0.10$ \\
\hline & $(0.12-0.91)$ & $(0.70-1.11)$ & (0.59-1.49) & $(0.10-1.07)$ & $(0.60-0.89)$ & $(0.35-1.09)$ & $(0.49-0.78)$ & \\
\hline \multirow[t]{2}{*}{$X V$} & $0.74 \pm 0.14$ & $0.95 \pm 0.17$ & $1.00 \pm 0.15$ & $0.89 \pm 0.19$ & $0.75 \pm 0.07$ & $0.76 \pm 0.11$ & $0.61 \pm 0.08$ & $0.81 \pm 0.14$ \\
\hline & $(0.08-0.96)$ & $(0.74-1.53)$ & (0.63-1.48) & $(0.66-1.39)$ & $(0.61-0.86)$ & $(0.54-0.98)$ & $(0.51-0.78)$ & \\
\hline \multirow[t]{2}{*}{$X V I$} & $0.76 \pm 0.10$ & $0.90 \pm 0.16$ & $0.87 \pm 0.14$ & $0.84 \pm 0.06$ & $0.74 \pm 0.08$ & $0.81 \pm 0.09$ & $0.61 \pm 0.10$ & $0.79 \pm 0.10$ \\
\hline & $(0.62-1.07)$ & $(0.73-1.20)$ & $(0.60-1.10)$ & $(0.74-1.02)$ & $(0.58-0.87)$ & $(0.62-1.07)$ & $(0.07-0.74)$ & \\
\hline \multirow[t]{2}{*}{ XVII } & $0.76 \pm 0.10$ & $0.88 \pm 0.16$ & $0.90 \pm 0.12$ & $0.84 \pm 0.10$ & $0.74 \pm 0.07$ & $0.79 \pm 0.11$ & $0.57 \pm 0.10$ & $0.78 \pm 0.11$ \\
\hline & $(0.56-0.97)$ & $(0.63-1.20)$ & $(0.69-1.16)$ & $(0.67-0.98)$ & $(0.57-0.86)$ & $(0.52-0.97)$ & $(0.37-0.77)$ & \\
\hline \multirow[t]{2}{*}{ XVIII } & $0.76 \pm 0.12$ & $0.91 \pm 0.13$ & $0.94 \pm 0.12$ & $0.83 \pm 0.10$ & $0.74 \pm 0.07$ & $0.77 \pm 0.09$ & $0.61 \pm 0.09$ & $0.79 \pm 0.11$ \\
\hline & $(0.57-0.99)$ & $(0.70-1.21)$ & $(0.65-1.27)$ & $(0.66-1.04)$ & $(0.51-0.89)$ & $(0.60-0.92)$ & $(0.27-0.76)$ & \\
\hline \multirow[t]{2}{*}{$X I X$} & $0.74 \pm 0.12$ & $0.89 \pm 0.22$ & $0.88 \pm 0.14$ & $0.83 \pm 0.07$ & $0.73 \pm 0.06$ & $0.77 \pm 0.10$ & $0.63 \pm 0.08$ & $0.78 \pm 0.09$ \\
\hline & $(0.58-1.13)$ & $(0.66-1.63)$ & $(0.63-1.23)$ & $(0.72-1.03)$ & $(0.63-0.84)$ & $(0.57-0.94)$ & $(0.49-0.75)$ & \\
\hline
\end{tabular}

Total number of samples: 4,641 . Values represent mean \pm standard deviation (SD). Data in parenthesis represent minimum and maximum values. 
solutions containing $0.1,0.2,0.4,0.8,1.6$, and 3.2 $\mathrm{mg} \mathrm{F} / \mathrm{L}$. Only calibration curves with a maximum variation of $5 \%$ were accepted. All analyses were performed in duplicate to test the repeatability of the readings. The reproducibility of the readings was assessed by making new measurements from $10 \%$ of the samples.

The samples were classified according to their fluoride levels based on risk (to develop dental fluorosis) and benefit (to prevent dental caries) considerations, according to CECOL/USP, $2011^{6}$. The risk was considered "insignificant" for samples with fluoride levels between 0 and $0.44 \mathrm{mg} / \mathrm{L}$; "low" for samples with fluoride levels between 0.45 and 0.84 $\mathrm{mg} / \mathrm{L}$; "moderate" for samples with fluoride levels between 0.85 and $1.14 \mathrm{mg} / \mathrm{L}$; "high" for samples with fluoride levels between 1.15 and $1.44 \mathrm{mg} / \mathrm{L}$; and "very high" for samples with fluoride levels $\geq 1.45 \mathrm{mg} / \mathrm{L}$. Considering the benefit, samples with fluoride levels ranging between 0 and $0.44 \mathrm{mg} / \mathrm{L}$ were considered "insignificant", while those with fluoride levels ranging between 0.45 and $0.54 \mathrm{mg} / \mathrm{L}$, 0.55 and $1.14 \mathrm{mg} / \mathrm{L}, 1.15-1.44 \mathrm{mg} / \mathrm{L}$, and $\geq 1.45$ $\mathrm{mg} / \mathrm{L}$ were regarded as "minimum", "maximum", "questionable", and "harmful", respectively (Table 2). According to this system of classification, the ideal interval for fluoride concentration in the drinking water samples should have been between 0.55 and $0.84 \mathrm{mg} / \mathrm{L}$ because that level is associated with low risk for the development of dental fluorosis and maximum benefit in relation to dental caries prevention.

Descriptive statistics were applied to the data, including absolute and relative frequencies, means, and standard deviations.

\section{RESULTS}

During the course of seven years, 4,641 samples were analyzed. The numbers of samples analyzed in the $1^{\text {st }}, 2^{\text {td }}, 3^{\text {rd }}, 4^{\text {th }}, 5^{\text {th }}, 6^{\text {th }}$, and $7^{\text {th }}$ years were 677 , $691,567,684,671,671$, and 680 , respectively. A total of 399 samples were lost or excluded during the period of collection due to a lack of water at the time of collection in some sectors or other technical problems.

Mean fluoride concentrations obtained for the 19 supply sectors in each year and for the seven years of collection are shown in Table 1 . The means for the seven years ranged between $0.73 \pm 0.08$ and $0.81 \pm 0.14 \mathrm{mg} \mathrm{F} / \mathrm{L}$. During that period of time, the lowest concentration found was $0.03 \mathrm{mg} \mathrm{F} / \mathrm{L}$, while the highest was $2.63 \mathrm{mg} \mathrm{F} / \mathrm{L}$. Observing the means of fluoride concentrations in Table 1, all the sectors were classified as of low or moderate risk and maximum benefit for all the studied years. However, in the last studied year $\left(7^{\text {th }}\right)$, there was a tendency for lower concentrations with sectors presenting fluoride concentrations means borderline to low risk and a minimum benefit classification.

Table 2 shows the classification of samples according to fluoride concentrations, based on risk/ benefit considerations ${ }^{6}$. The percentage of samples classified as low risk for dental fluorosis and maximum benefit for caries prevention (0.55-0.84 $\mathrm{mg} \mathrm{F} / \mathrm{L}$ ) during the seven years of the study was $69 \%$. Regarding the individual years, most of the samples were classified as minimum or moderate risk and maximum benefit.

Table 2- Classification of samples according to the fluoride concentration (mg/L) in Bauru, Brazil, from March/2004 to February/2011

\begin{tabular}{|c|c|c|c|c|c|c|c|c|c|c|}
\hline \multirow{2}{*}{$\begin{array}{c}\text { F concentration } \\
\mathrm{mg} / \mathrm{L} \\
\end{array}$} & \multirow{2}{*}{$\begin{array}{c}1^{\text {st }} \\
\text { year } \\
\mathrm{n}(\%) \\
\end{array}$} & \multirow{2}{*}{$\begin{array}{c}2^{\text {nd }} \\
\text { year } \\
\mathrm{n}(\%) \\
\end{array}$} & \multirow{2}{*}{$\begin{array}{c}3^{\text {rd }} \\
\text { year } \\
\mathrm{n}(\%) \\
\end{array}$} & \multirow{2}{*}{$\begin{array}{c}4^{\text {th }} \\
\text { year } \\
\mathrm{n}(\%) \\
\end{array}$} & \multirow{2}{*}{$\begin{array}{c}5^{\text {th }} \\
\text { year } \\
\mathrm{n}(\%) \\
\end{array}$} & \multirow{2}{*}{$\begin{array}{c}6^{\text {th }} \\
\text { year } \\
\mathrm{n}(\%)\end{array}$} & \multirow{2}{*}{$\begin{array}{c}7^{\text {th }} \\
\text { year } \\
\mathrm{n}(\%)\end{array}$} & \multirow{2}{*}{$\begin{array}{l}\text { Total } \\
\text { n (\%) } \\
\end{array}$} & \multicolumn{2}{|c|}{ Classification * } \\
\hline & & & & & & & & & Risk & Benefit \\
\hline \multirow[t]{2}{*}{$0-0.44$} & 12 & 3 & 2 & 7 & 0 & 4 & 20 & 48 & insignificant & insignificant \\
\hline & $(1.8)$ & $(0.4)$ & $(0.4)$ & (1.0) & $(0.0)$ & $(0.6)$ & $(2.9)$ & $(1.0)$ & & \\
\hline \multirow[t]{2}{*}{$0.45-0.54$} & 3 & 0 & 1 & 3 & 9 & 20 & 162 & 198 & low & minimum \\
\hline & $(0.4)$ & $(0.0)$ & $(0.2)$ & $(0.4)$ & $(1.3)$ & $(3.0)$ & (23.8) & (4.3) & & \\
\hline \multirow[t]{2}{*}{$0.55-0.84$} & 555 & 404 & 212 & 417 & 603 & 519 & 492 & 3202 & low & maximum \\
\hline & (82.0) & $(58.5)$ & $(37.4)$ & $(61.0)$ & (89.9) & (77.3) & (72.4) & $(69.0)$ & & \\
\hline \multirow[t]{2}{*}{$0.85-1.14$} & 106 & 246 & 328 & 246 & 59 & 127 & 5 & 1117 & moderate & maximum \\
\hline & (15.7) & $(35.6)$ & $(57.8)$ & $(36.0)$ & (8.8) & (18.9) & $(0.7)$ & $(24.1)$ & & \\
\hline \multirow[t]{2}{*}{$1.15-1.44$} & 1 & 33 & 22 & 8 & 0 & 0 & 0 & 64 & high & questionable \\
\hline & $(0.1)$ & $(4.8)$ & (3.9) & (1.2) & $(0.0)$ & $(0.0)$ & $(0.0)$ & (1.4) & & \\
\hline \multirow[t]{2}{*}{$>=1.45$} & 0 & 5 & 2 & 3 & 0 & 1 & 1 & 12 & very high & harmful \\
\hline & $(0.0)$ & $(0.7)$ & $(0.4)$ & $(0.4)$ & $(0.0)$ & $(0.1)$ & $(0.1)$ & $(0.3)$ & & \\
\hline \multirow[t]{2}{*}{$n$} & 677 & 691 & 567 & 684 & 671 & 671 & 680 & 4641 & & \\
\hline & (14.6) & (14.9) & $(12.2)$ & (14.7) & (14.5) & (14.5) & (14.7) & $(100.0)$ & & \\
\hline
\end{tabular}

${ }^{*}$ According to CECOL/USP6, 2011. 


\section{DISCUSSION}

External control over the fluoridation of the public water supply was implemented in Bauru due to fluctuations in public water fluoride levels that were revealed in previous studies $5,17,31$. In Bauru, the Water and Sewage Department is a municipal organ. The researchers decided that, for this reason, it would not be appropriate for external control of the water fluoride levels to be implemented by the Health Department of the city because it is also a municipal organ ${ }^{6}$. When conducted by an institution not involved in the fluoridation procedure, monitoring adds impartiality and credibility to the results obtained ${ }^{24}$.

To conduct the study, the city was divided into 19 sectors, each of which has its own characteristics and because water fluoridation is performed individually in each of them. Thus, the researchers determined that the calculation of a mean water fluoride concentration for the whole city would not be of practical relevance, as the citywide average might mask a fluoridation problem in one or more sectors. This would provide information that would not correspond to the real situation of the fluoridation status in the water supply of the city as a whole.

As can be seen in Tables 1 and 2, there was considerable improvement in the quality of fluoridation of the public water supply in the city of Bauru during the period of the study when compared to results from previous studies, $5,17,31$. In 1997, there was a variation of between 0.05 and $1.40 \mathrm{mg} \mathrm{F} / \mathrm{L}$ in the 330 samples of public water analyzed. Only $16.36 \%$ of the samples in that study presented optimum fluoride levels (0.6-0.8 mg/L) ${ }^{31}$. In 2002, fluoride concentrations were lower than optimum $(0.8 \mathrm{mg} / \mathrm{L})$ in $89 \%$ of the samples analyzed. Additionally, a very wide range was observed (between 0.01 and $9.35 \mathrm{mg}$ $\mathrm{F} / \mathrm{L})^{5}$. In 2006 , it was reported that the fluoride concentrations of the water samples varied between 0.31 and $2.01 \mathrm{mg} \mathrm{F} / \mathrm{L}$. Nearly $56 \%$ of the samples were classified as acceptable during the period between October/2002 and March/200317.

During the seven years of monitoring for the present study, $69 \%$ of the samples presented fluoride concentrations ranging between 0.55 and $0.84 \mathrm{mg} \mathrm{F} / \mathrm{L}$, which is classified as low risk for the development of dental fluorosis and maximum benefit for the prevention of dental caries ${ }^{6}$. Even during the first year after implementation of external control, positive results were observed, i.e., $82 \%$ of the samples analyzed were classified as low risk and maximum benefit, according to their fluoride levels. These results were similar to those reported for the city of Campo Grande (in the midwest region of Brazil) ${ }^{2}$. On the other hand, they were much more favorable than those reported for three cities in the state of Piauí (in the northeast region of Brazil) since only $4.3 \%$ of the analyzed samples presented optimum fluoride concentrations ${ }^{30}$. The improvement may be due to the fact that the Water and Sewage Department of Bauru had been informed of the previous results showing large fluctuations in public water fluoride concentrations ${ }^{5}$ and about the implementation of the external control.

However, between the second and fourth years of monitoring, the number of samples considered low risk and of maximum benefit diminished, mainly due to an increase in the number of over-fluoridated samples. However, in most of the cases, the fluoride levels ranged between 0.85 and $1.14 \mathrm{mg} / \mathrm{L}$, which is classified as of moderate risk and maximum benefit ${ }^{6}$. It must be highlighted that these levels of fluoride were found in samples collected only one day during each month, i.e., they may not be representative of the entire month. In addition, it has been reported that, in schoolchildren, perceived esthetic problems attributed to water fluoridation is very low ${ }^{11}$.

Failures in the water fluoridation process are mainly related to temperature, instability of the fluoride salt, and difficulties in reference to keeping the system working ${ }^{15}$. The Water and Sewage Department was advised about the tendency toward over-fluoridation during the second, third, and fourth years of external control. This might have led to the considerable improvement in the quality of water fluoridation that could be seen during the fifth year, when around $90 \%$ of the samples were classified as of low risk and maximum benefit. However, during the sixth and seventh years of monitoring, the percentage of samples classified as of low risk and maximum benefit decreased again. This indicates that the external monitoring, after having been implemented, should be continued for a long period of time. It is important to mention that as part of the program of external control as a whole, the results obtained are published yearly in a local newspaper in order to inform the population. This is an important measure that should be maintained.

In-line with the findings of the present study, an improvement in the quality of the fluoridation in Chapecó (in the south region of Brazil) was observed 10 years after the implementation of external control ${ }^{25}$. Therefore, it is clear that external control over water supply fluoridation plays an extremely important role in terms of its additional efforts toward improving the oral health conditions of the population and should be guaranteed by government and social control.

Despite the fact that Federal ${ }^{3}$ and State $^{29}$ Brazilian laws have set the maximum value for 
fluoride concentration in water at $1.0 \mathrm{mg} \mathrm{F} / \mathrm{L}$, the Ministry of Health accepts concentrations up to 1.5 $\mathrm{mg} F / L$ as the upper limit of potability ${ }^{22}$. Brazil is a country of great territorial extension with a wide range of different temperatures, which makes the determination of a unique range of concentrations for the entire country extremely difficult. These disparities make water fluoridation even more difficult to control. It is important to emphasize the fact that fluctuations in fluoride concentrations in water as low as $0.2 \mathrm{mg} / \mathrm{L}$ can result in measurable alterations in the prevalence and severity of dental fluorosis ${ }^{1}$. On the other hand, under-fluoridation can lead to ineffective control of dental caries ${ }^{9}$.

The benefit of the fluoridation of public water is proportionally larger in the segments of society that do not have access to other fluoride sources such as fluoride dentifrices and which, therefore, need it the most ${ }^{14}$. However, fluoride levels in drinking water have to be adequate to prevent dental caries and, at the same time, not increase the risk for dental fluorosis.

In summary, the results of the present study reinforce the belief in the importance of the implementation and maintenance of external control of fluoride in water supplies to improve the consistency of water fluoridation. External control should be implemented wherever there is adjusted fluoridation, and certainly in communities where fluctuations in water fluoride levels have been revealed. This measure is fundamental to achieve the maximum benefits of water fluoridation, which contributes to improve the oral health condition of people who drink water from those supplies.

\section{ACKNOWLEDGEMENTS}

This study was supported by CNPq (Conselho Nacional de Desenvolvimento Científico e Tecnológico, Edital Saúde Bucal, Grant 403427/2004-5).

\section{CONFLICTS OF INTEREST}

The authors have no conflict of interest to declare.

\section{REFERENCES}

1- Aoba T, Fejerskov O. Dental fluorosis: chemistry and biology. Crit Rev Oral Biol Med. 2002;13:155-70.

2- Bellé BLL, Lacerda VR, De Carli AD, Zafalon EJ, Pereira PZ. Análise da fluoretação da água de abastecimento público da zona urbana do município de Campo Grande (MS). Cien Saude Colet. 2009;14:1261-6.

3- Brasil. Lei no 6050, de 24 de maio de 1974. Dispõe sobre a fluoretação da água em sistemas de abastecimento quando existir estação de tratamento. [cited 18 Jun 2010]. Available from: <http://www.planalto.gov.br/ccivil_03/Leis/L6050.htm>.
4- Brasil. Decreto no 76.872, de 22 dezembro 1975. Regulamenta a lei no 6.050, de 24 de maio de 1974, que dispõe sobre a fluoretação da água em sistemas públicos de abastecimento. Diário Oficial da União. Brasília, 22 dez 1975. Available from: <http:// www.planalto.gov.br/ccivil_03/decreto/Antigos/D76872.htm>.

5- Buzalaf MA, Granjeiro JM, Damante CA, Ornelas F. Fluctuations in a public water fluoride level in Bauru, Brazil. J Public Health Dent. 2002;62:173-6.

6- Collaborative Center of Brazilian Health Ministry for Oral Health Surveillance - CECOL/USP. Drinking water classification according to fluoride concentration: a technical consensus statement. São Paulo: Public Health School of São Paulo University; 2011.

7- Centers for Disease Control and Prevention. Achievements in public health, 1900-1999: fluoridation of drinking water to prevent dental caries. JAMA. 2000;283:1283-6.

8- Dean HT, Arnold FA Jr, Elvove E. Domestic water and dental caries. V. Additional studies of the relation of fluoride domestic waters to dental caries experience in 4,425 white children aged 12-14 years of 13 cities in 4 states. Publ Health Rep. 1942;57:1155-79.

9- Dean HT, Elvove E. Further studies on the minimum threshold of chronic endemic dental fluorosis. Publ Health Rep. 1937;52:124964.

10- Featherstone JD. Prevention and reversal of dental caries: role of low level fluoride. Community Dent Oral Epidemiol. 1999;27:31-40.

11- Griffin SO, Beltrán ED, Lockwood SA, Barker LK. Esthetically objectionable fluorosis attributable to water fluoridation. Community Dent Oral Epidemiol. 2002;30(3):199-209

12- Instituto Brasileiro de Geografia e Estatística (IBGE). Cidades. Bauru. [cited 2011 Apr 14] Available from: <http://www.ibge.gov. $\mathrm{br} /$ cidadesat/topwindow.htm?1>.

13- Instituto de Pesquisas Meteorológicas (IPMet). Características da Estação do Verão. Comportamento da Região de Bauru. [cited $2011 \mathrm{Apr}$ 15]. Available from: <http://www.ipmet.unesp. br/4estacoes/\#>.

14- Jones $\mathrm{CM}$, Worthington $\mathrm{H}$. Water fluoridation, poverty and tooth decay in 12-year-old children. J Dent. 2000;28:389-93.

15- Kuthy RA, Naleway C, Durkee J. Factors associated with maintenance of proper water fluoride levels. J Am Dent Assoc. 1985;110:511-3.

16- Lima FG, Lund RG, Justino LM, Demarco FF, Del Pino FA, Ferreira R. Vinte e quatro meses de heterocontrole da fluoretação das águas de abastecimento público de Pelotas, Rio Grande do Sul, Brasil. Cad Saúde Pública. 2004;20:422-9.

17- Lodi CS, Ramires I, Buzalaf MA, Bastos JR. Fluoride concentration in water at the area supplied by the Water Treatment Station of Bauru, SP. J Appl Oral Sci. 2006;14:365-70.

18- Maia LC, Valença AM, Soares EL, Cury JA. Controle operacional da fluoretação da água de Niterói, Rio de Janeiro, Brasil. Cad Saúde Pública. 2003;19:61-7.

19- Mascarenhas AK, Mashabi S. High fluoride concentration in drinking water may increase the prevalence and severity of dental fluorosis, and decrease occurrence of caries. J Evid Based Dent Pract. 2008;8:15-6.

20- McDonagh MS, Whiting PF, Wilson PM, Sutton AJ, Chestnutt I, Cooper J, et al. Systematic review of water fluoridation. BMJ. 2000;321:855-9.

21- Brasil. Ministério da Saúde. Portaria n 635, de 26 de dezembro de 1975. Aprova normas e padrões a seguir sobre fluoretação da água dos sistemas públicos de abastecimento, destinada ao consumo humano. Diário Oficial União, Brasília, 30 jan. 1976. 22- Brasil. Ministério da Saúde. Portaria no 518, de 25 de março de 2004. Estabelece os procedimentos e responsabilidades relativas ao controle e vigilância da qualidade da água para o consumo humano e seu padrão de potabilidade, e dá outras providências. Diário Oficial da União, 16 mar 2004. Seção 1, p. 266-70.

23- Narvai PC. Cárie dentária e flúor: uma relação do século XX. Ciênc Saúde Coletiva. 2000;5:381-92. 
24- Narvai PC. Fluoretação da água: heterocontrole no município de São Paulo no período de 1900-1999. Rev Bras Odontol Saude Coletiva. 2000;1:50-6.

25- Panizzi M, Peres MA. Dez anos de heterocontrole da fluoretação de águas em Chapecó, Estado de Santa Catarina, Brasil. Cad Saúde Publica. 2008;24:2021-31.

26- Ramires I, Maia LP, Rigolizzo DS, Lauris JR, Buzalaf MA. External control over the fluoridation of the public water supply in Bauru, SP, Brazil. Rev Saude Publica. 2006;40:883-9.

27- Rugg-Gunn A, Villa AE, Buzalaf MAR. Contemporary biological markers of exposure to fluoride. In: Buzalaf MAR. (ed). Fluoride and the oral environment. Basel: Karger; 2011. pp 37-51.

28- Saliba NA, Moimaz SA, Tiano AV. Fluoride level in public water supplies of cities from the northwest region of São Paulo State, Brazil. J Appl Oral Sci. 2006;14:346-50.

29- Secretaria da Saúde de São Paulo. Resolução no SS-250, de 15 de agosto de 1995. Define teores de concentração do íon fluoreto nas águas para consumo humano, fornecidas por sistemas públicos de abastecimento. Diário Oficial do Estado de SP, São Paulo, 15 ago 1995.
30- Silva JS, Val CM, Costa JN, Moura MS, Silva TAE, Sampaio FC. Heterocontrole da fluoretação das águas em três cidades no Piauí, Brasil. Cad. Saúde Pública. 2007;23:1083-8.

31- Tavares PG, Bastos JRM. Concentração de flúor na água: cárie, fluorose e teor de flúor urinário em escolares de Bauru-SP. Rev Ass Paul Cirur Dent. 1999;53:407-15.

32- Ten Cate JM. Review on fluoride, with special emphasis on calcium fluoride mechanisms in caries prevention. Eur J Oral Sci. 1997; 105:461-5.

33- Toassi RF, Kuhnen M, Cislaghi GA, Bernardo JR. Heterocontrole da fluoretação da água de abastecimento público de Lages, Santa Catarina, Brasil. Ciência \& Saúde Coletiva. 2007;12:727-32.

34- Yeung CA. A systematic review of the efficacy and safety of fluoridation. Evid Based Dent. 2008;9:39-43. 